\title{
THE VIOLA IN AMERICA: TWO CENTURIES OF PROGRESS
}

\author{
By David M. Bynog
}

In the summer of 2010, the American Viola Society (AVS) officially launched the American Viola Project. As part of a larger effort to make scores available for research and performance, the American Viola Project aims to collect, publish, and preserve viola music from the United States by making scores freely accessible on the society's Web site at: http://americanviolasociety.org/resources/scores/american-violaproject/. The digital project includes compositions that are newly published under the AVS Publications name, scanned copies of previously published compositions, and works provided directly from contemporary composers. All pieces are either in the public domain or authorized for inclusion by the copyright holders.

Preliminary work on the project began by surveying repertoire to locate compositions that were in the public domain. Only a few viola compositions published in America before $1923^{1}$ are widely known, namely Ernest Bloch's Suite, published by Schirmer in 1920, and chamber works by Charles Martin Loeffler featuring the viola: the Deux rapsodies, for oboe, viola, and piano (published by Schirmer in 1905); and the Quatre poёmes, op. 5, for voice, viola, and piano (published by Schirmer in 1904). Library catalogs and bibliographies of string music were examined to locate music suitable for the project. One public-domain work identified early in the project was a viola sonata by the New York-native Frank Limbert (1866-1938), published in 1892. In this instance, rather than scan a copy for inclusion on the AVS Web site, the organization requested that the Sibley Music Library scan its copy and add to its institutional repository at the University of Rochester. ${ }^{2}$

More problematic for the project was the dearth of research focused on the viola in America prior to the twentieth century. So, the initial

David M. Bynog is assistant head of Acquisitions, Fondren Library, Rice University. He has served as the editor of the Journal of the American Viola Society since 2008, and in 2010 he founded the American Viola Project.

1. Works registered or first published in America before 1923 are automatically in the public domain owing to the expiration of copyright.

2. Frank L. Limbert, Sonate (C moll) für Pianoforte und Viola, op. 7 (Frankfurt: Steyl \& Thomas, 1892), https://urresearch.rochester.edu/viewContributorPage.action;jsessionid=FDE55852A80BCC0633BE042 870E7D871? personNameId=3583 (accessed 22 February 2012). 
objective of preserving American viola repertoire broadened into a fuller investigation of the early history of the instrument and its performers in America. This article briefly surveys the history of the instrument in America prior to 1920, and provides background on the society's efforts to uncover American viola repertoire.

\section{EARLY SIGHTINGS: $1720 S-1788$}

Terminology is the largest obstacle to tracing the early history of the viola in America. Following the practice in England, the viola was typically referred to as a "tenor" or "tenor violin" during the colonial period. But a host of other terms, including tenor viol, tenor fiddle, or large violin may also refer to a viola. Since instruments of the violin and viol families coexisted in colonial America, definitively classifying an instrument as a viola based on references to a "tenor" can be problematic. ${ }^{3}$ Similarly, the term "large violin" poses problems as it may simply refer to a violin, to differentiate it from a kit (or small violin). Violas, even in the twentyfirst century, are frequently misidentified as violins, so a viola may easily have been recorded as a violin or fiddle in household inventories, records of concerts, or in newspaper advertisements. Regardless of inconsistencies in terminology, violas were not particularly popular instruments during the colonial period, so most identifiable references to violas in the first part of the century are found in very wealthy households or in areas with substantial musical activities.

The presence of a viola in America is known by the $1720 \mathrm{~s}$, as the household inventory of William Burnet records a "large Violin or Tenor fidle." 4 Burnet, who served as governor of New York and New Jersey and later the Massachusetts Bay Colony, lived a life befitting that of his political position. His possessions were extensive, including modern conveniences and the finest furnishings that breathed "an atmosphere of ease and luxury that one would scarcely expect to find in New York during the third decade of the eighteenth century." ${ }^{5}$ Numbered among his household inventory lists were "A Large bass violine, Two Trible Violins, A Harpsicord," and "Two Brass Trumpets." 6 With such a large number of

3. For example, the merchant Henry Callister was in possession of a "tenor fiddle" in the 1750 sgenerally speculated to have been a viola da gamba. See John Barry Talley, Secular Music in Colonial Annapolis: The Tuesday Club, 1745-56, Music in American Life (Urbana: University of Illinois Press, 1988), 25.

4. Barbara Lambert, "Social Music, Musicians, and Their Musical Instruments In and Around Colonial Boston," in Music in Colonial Massachusetts, 1630-1820: A Conference Held by the Colonial Society of Massachusetts, May 17 and 18, 1973, ed. Barbara Lambert, vol. 2, Music in Homes and in Churches, Publications of the Colonial Society of Massachusetts, 54 (Boston: Colonial Society of Massachusetts, dist. by the University Press of Virginia, 1985), 499-500. A detail of the manuscript inventory listing this viola appears as fig. 270 on p. 500.

5. Esther Singleton, The Furniture of Our Forefathers (New York: Doubleday, Page, 1908), 276.

6. Lambert, [431]. 
musical instruments in the household, musical entertainment was probably common, and the variety of instruments would have allowed the most fashionable music to be performed.

An early use of a viola in a public concert dates from Christmas Day, 1743, when the Moravian settlement in Bethlehem, Pennsylvania, used a violin, viola da braccio, viola da gamba, flutes, and French horns in a worship service. ${ }^{7}$ The Moravians in America were great lovers of instrumental music, and they used instruments both for sacred and secular purposes. Their affection for instrumental music making led to the rise of the collegia musica, a loosely defined term that denoted gatherings of amateur musicians for sessions that were both entertaining and instructional. ${ }^{8}$ A collegium musicum in an American Moravian settlement is known as early as January $1731,{ }^{9}$ and the groups became leadingthough isolated-forces in American musical growth during the eighteenth century. Violas were a necessity for the large portion of chamber music performed by these groups as well as for performances of anthems, the chief form of choral music in the Moravian church. These anthems were typically "written for a four-part mixed choir accompanied by a string orchestra (two violins, viola, cello, and bass) and keyboard."10

To fulfill the need for violas by the Moravian settlements, members built the instruments themselves. One such viola, believed to be the earliest extant viola made in America, ${ }^{11}$ was constructed by John Antes and is housed in the Lititz Congregation Collection (fig. 1). The instrument bears the label "Johann Antes, me fecit in Bethlehem 1764"12 and measures sixteen inches. Records from Antes's shop show a payment for an earlier viola in 1763, ${ }^{13}$ and Azariah Smith built a viola in Christianspring, Pennsylvania, in $1765 .^{14}$

Interest in violas was not limited to Moravian settlements. Beginning with William Burnet's viola from the 1720s, references to violas in New York can be found throughout the eighteenth century. In 1753, Charles

7. Maurer Maurer, "Music in Wachovia, 1753-1800," William and Mary Quarterly, 3d ser., vol. 8, no. 2 (April 1951): 219.

8. Nola Reed Knouse, "The Collegia Musica: Music of the Community," in The Music of the Moravian Church in America, ed. Nola Reed Knouse, Eastman Studies in Music, [49] (Rochester, NY: University of Rochester Press, 2008), 190.

9. Ibid., 191.

10. Alice M. Caldwell, "Moravian Sacred Vocal Music," in The Music of the Moravian Church in America, 97.

11. See below for details on a recently discovered viola, possibly from an earlier date, that is now in the collection of the Metropolitan Museum of Art

12. Marian L. Shatto, "John Antes, Instrument Maker," Church Square Journal 12 (Fall 2009): 4, http://www.lititzmoravian.org/userfiles/file/Church_square_journal_Fall09(1).pdf (accessed 22 February 2012).

13. Ibid.

14. Donald M. McCorkle, The Moravian Contribution to American Music, Moravian Music Foundation Publications, 1 (Winston-Salem, NC: Moravian Music Foundation, 1956), 6; reprinted from Notes 13, no. 4 (September 1956): 597-606. 


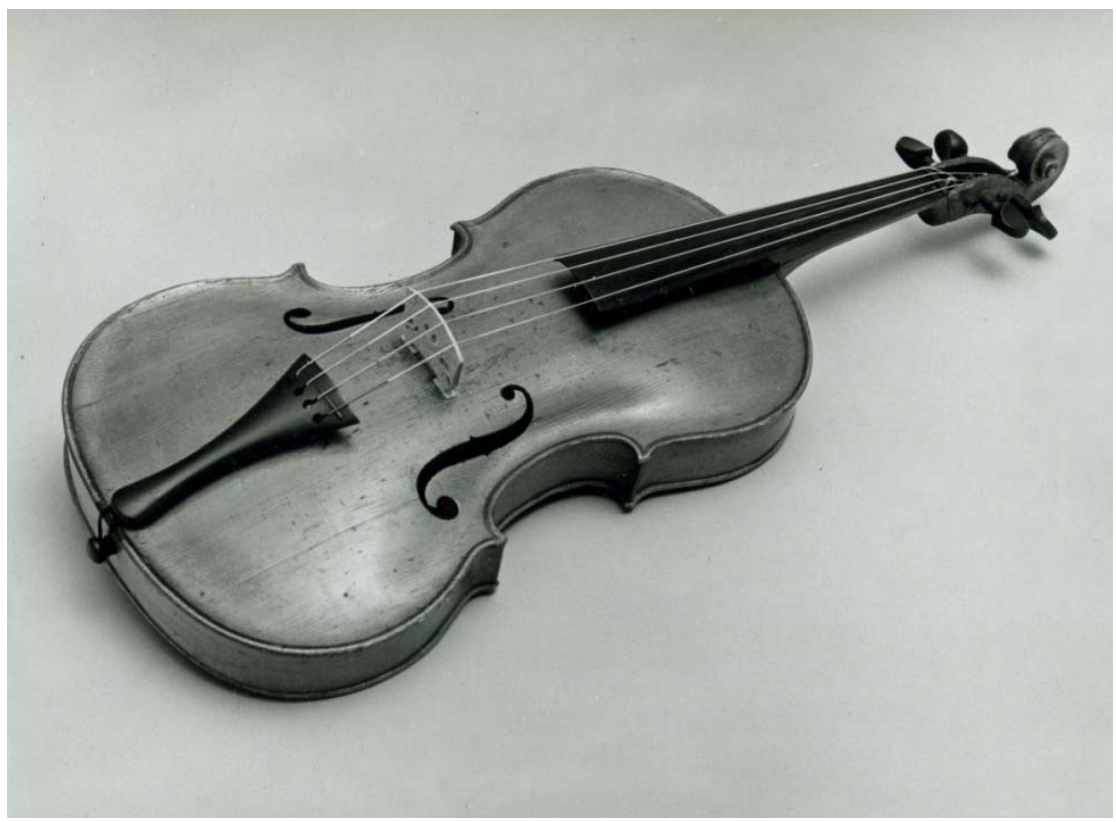

Fig. 1. John Antes's 1764 viola (photo courtesy of the Wayne LeFevre Collection, Lititz Moravian Congregation)

Love proposed "teaching gentlemen musick on the following instruments, viz. Violin, Hautboy, German and Common Flutes, Bassoon, French Horn, Tenor, and Bass Violin, if desired." 15 The tenor violin was also among the group of instruments that Alexander Van Dienval continued to teach in an advertisement from $1762,{ }^{16}$ and a tenor violin was among the items in a collection of "Musick \& Instruments, To be dispos'd of by a Gentleman lately arrived from LONDON."17

There are also references to viola making in colonial New York. Jacob Trippell, from London, advertised in 1764 that he made and repaired instruments, including tenor viols. ${ }^{18}$ In 1767 , a musical instrument maker by the name of Robert Horne advertised as "HAVING just arrived with a Parcel of fine VIOLINS, \&c,"19 and later advertised that he "MAKES and

15. "Charles Love, Musician," New-York Mercury, 9 July 1753.

16. "A Publick and Weekly Concert of Musick," New-York Gazette, 24 May 1762.

17. New-York Mercury, 9 August 1762.

18. "Jacob Trippell, Musical Instrument Maker from London," New-York Gazette, 12 November 1764.

19. "Robert Horne, Musical Instrument Maker from London," New-York Mercury, 4 May 1767. 
repairs violins, bass viols, tenor viols, Eolius harps, gauiters, German flutes, kitts, violin bows, \&c. in the neatest and compleatest manner."20

An early viola linked to New York has recently surfaced and is now in the collection of the Metropolitan Museum of Art. ${ }^{21}$ The viola is labeled "Made by / Robt. Horne / New York / 1757" (fig. 2) and if the date is accurate, this instrument would predate both the viola made by John Antes in 1764 and a violin made by Antes in 1759, the earliest extant violin made in America. Further research is necessary to determine the accuracy of the date on the label of this instrument, particularly since it predates by a decade the known references to a New York instrument maker named Robert Horne, ${ }^{22}$ but the existence of the instrument and the early advertisements for viola makers demonstrate the elevated interest in the viola.

Violas were also to be found in Virginia, where music making was a respectable activity for gentlemen. A Virginia concert advertised in 1766 listed the instrumentation as " 3 violins, 1 Tenor, 1 Bass, 2 Flutes, 1 Hautboy, 1 Horn, and 1 Harpsichord." 23 A tenor violin also appears in the estate inventory for Francis Fauquier, the lieutenant governor for the Virginia Colony. ${ }^{24}$ Fauquier held weekly gatherings of amateur musicians where John Tyler and Thomas Jefferson were known to perform violin. ${ }^{25}$ Given the frequency of music gatherings, Fauquier's viola was likely used on occasion.

\section{THE FIRST ADVOCATES: 1789-1840}

The end of the eighteenth century saw an increase in violas and violists in America, largely fueled by the dominance of the string quartet and the symphony as instrumental forms. And, by the federal period, the viola also was gaining a foothold as a solo instrument. Still, throughout much of America, violas would remain scarce, with pockets of activity in large musical centers.

The Moravian settlements would continue to play an important role in the advancement of the viola. In 1789 Johann Friedrich Peter (17461813) completed his set of Six Quintets, the earliest known chamber music composed in America. Peter, considered by many as the greatest

\footnotetext{
20. "Robert Horne, Musical Instrument-Maker, from London, at Mr. Francis Cooley's, on Golden Hill," New-York Mercury, 14 September 1767.

21. Purchased at Christie's Fine Musical Instruments, Sale 1816, 2 April 2007, lot 170.

22. "Dendrochronological testing to determine more closely the dating has not yet been possible, though there are plans to do so." Jayson Kerr Dobney (associate curator, Department of Musical Instruments, The Metropolitan Museum of Art), e-mail message to author, 5 December 2011.

23. Virginia Gazette, 11 December 1766, quoted in Albert Stoutamire, Music of the Old South: Colony to Confederacy (Rutherford, NJ: Fairleigh Dickinson University Press, 1972), 48.

24. The Official Papers of Francis Fauquier, Lieutenant Governor of Virginia, 1758-1768, ed. George Reese, 3 vols., Virginia Historical Society Documents, 14-16 (Charlottesville: University Press of Virginia, 1980), 1:xlii.

25. Helen Cripe, Thomas Jefferson and Music (Charlottesville: University Press of Virginia, 1974), 14.
} 


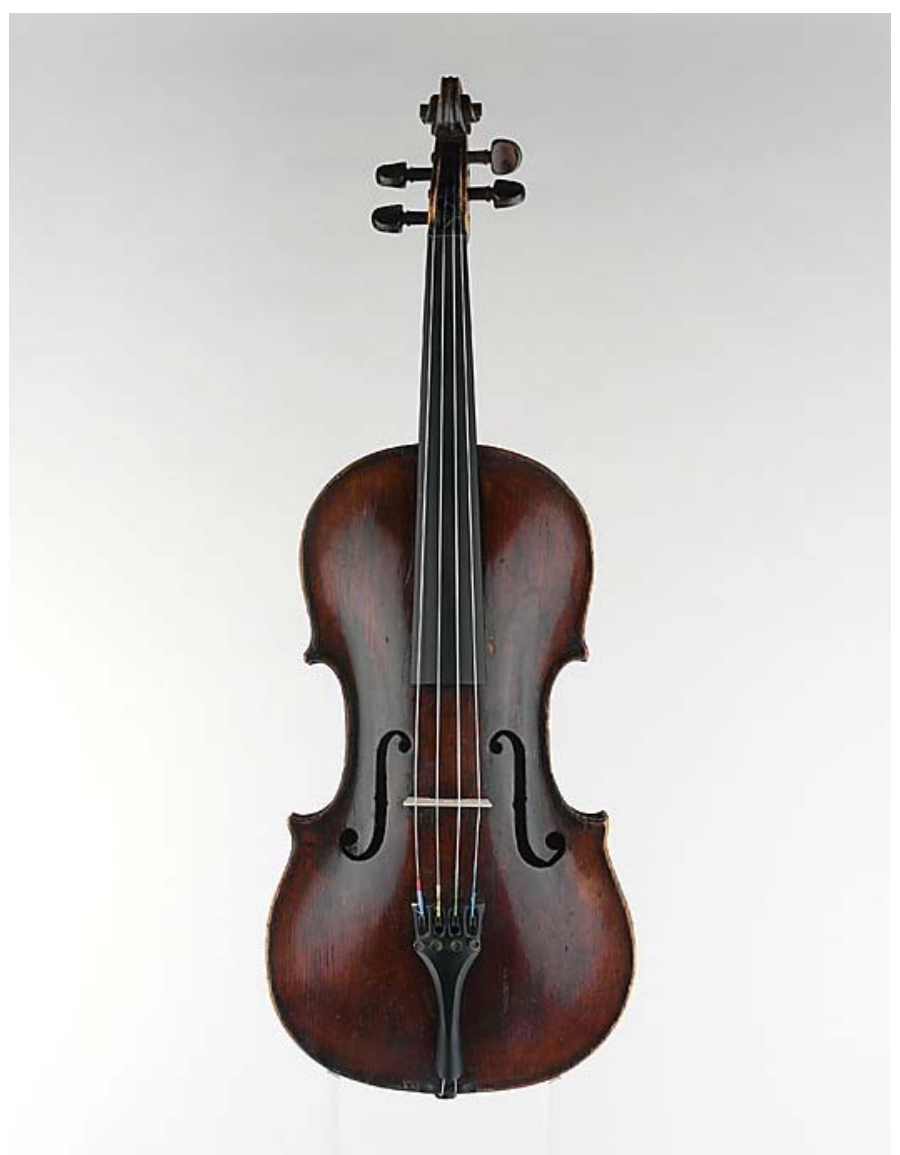

Fig. 2. Viola. 1757. Made by Robert M. Horne in New York, NY. Wood, L. $41.8 \mathrm{~cm}$ (16 7/16 in.). Purchase, Frederick M. Lehman Bequest, 2007 (2007.228). The Metropolitan Museum of Art, New York, NY, U.S.A. Image copyright ( $)$ The Metropolitan Museum of Art. Image source: Art Resource, NY

of Moravian musicians, came to America in 1770. He brought with him a large collection of works that he had copied while in Europe; these served as a core repertoire for the collegia musica. Scored for two violins, two violas, and cello (viola quintet), Peter's quintets were likely written over a number of years. ${ }^{26}$ Research on these quintets has suggested that

26. The score is dated 9 January and the parts dated 28 February, leading some to conclude that these quintets were composed in less than two months. Donald McCorkle notes that "it is difficult to believe that Peter could have produced such carefully wrought and lengthy ... compositions in so short a time. It is more likely that he was occupied with them spasmodically for several years, working on them whenever time permitted." Donald M. McCorkle, "Moravian Music in Salem: A German-American Heritage" (Ph.D. diss., Indiana University, 1958), 153. 
they were composed with specific performers in mind from Salem's collegium musicum, which Peter had been involved with since 1780, and that the parts were written to conform to those players' abilities. ${ }^{27}$ However, the instrumentation of these works, requiring two violas, is surprising for this period in America. The viola quintet as a genre had been in existence since the 1750s, and in 1788 Salem's collegium musicum possessed two violas, so the instruments were available to perform compositions requiring more than one viola part. ${ }^{28}$ But, most ensembles in Americaincluding other Moravian settlements-were fortunate to have even one viola, so performances of a work that required two violas would be impractical if not completely unmanageable.

Given that most eighteenth-century musicians played more than one instrument (and nearly all viola players also played violin or a wind instrument), if Peter wrote these works with five specific players in mind, why did he choose the instrumentation of a viola quintet? Of the more than sixty works copied by Peter that are known to have been available for performances during the 1780s by Salem's collegium musicum, none have parts for more than one viola, ${ }^{29}$ and none of Peter's vocal music contains more than one viola part. If he wanted five string instruments, the instrumentation of three violins, viola, and cello would have been a much more feasible grouping. This instrumentation was already used in the 1770 s by Immanuel Nitschmann, who had arranged arias from operas for three violins, viola, and figured bass for use by the collegium musicum..$^{30}$

For whatever reasons, Peter conscientiously chose to include two violas in his only secular compositions, despite any obstacles for locating instruments and performers. Even more significant is his writing for both of the viola parts. The viola I part contains more melodic material and more technically difficult material than the viola II part, but both contain challenging material that would require skilled players. Peter varies the part-writing among the six quintets, but the two viola parts, particularly in melodic sections, are often written in parallel thirds or sixths with the viola I taking the higher part (fig. 3). Though the viola II part does not venture beyond first position (the viola I part goes only to third position; typical for chamber music in the eighteenth century), it does have

27. See, for example, John Frederick Boewe, "The String Quintets of Johann Friedrich Peter" (M.Mus. thesis, University of Illinois at Urbana-Champaign, 1957), 55; and Ronald Michael Spier, "The Compositional Style of Johann Friedrich Peter as Influenced by Franz Xaver Richter" (M.A. thesis, San Diego State University, 1976), 28.

28. Knouse, 196.

29. For more details on the repertoire, see Thomas Jerome Anderson, "The Collegium Musicum Salem, 1780-1790: Origins and Repertoire" (Ph.D. diss., Florida State University, 1976).

30. Hans T. David, Musical Life in the Pennsylvania Settlements of the Unitas Fratrum, Moravian Music Foundation Publications, 6 (Winston-Salem, NC: Moravian Music Foundation, 1959), 19. 

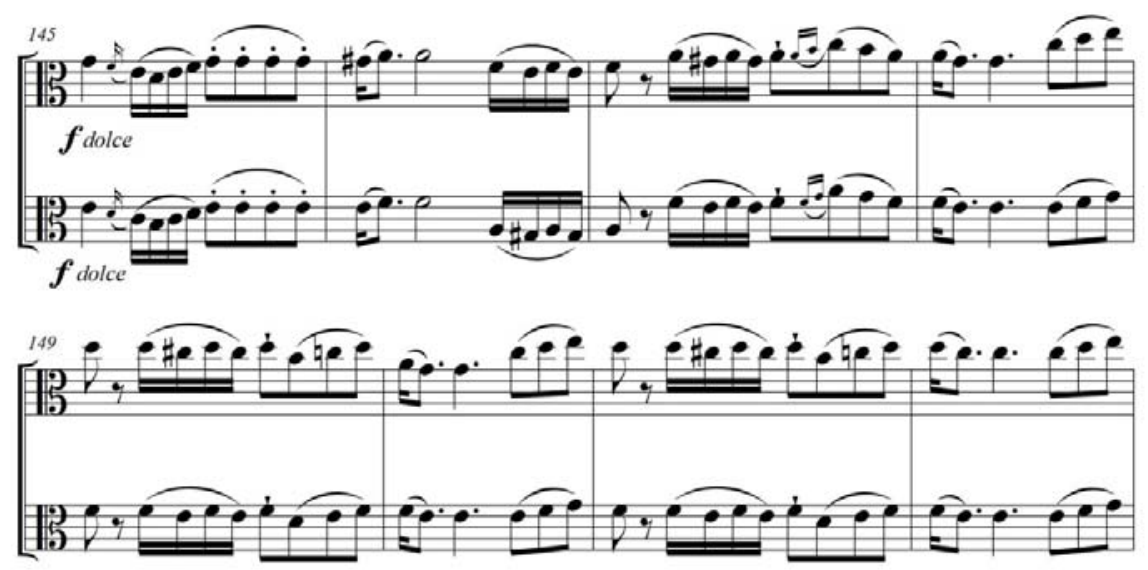

Fig 3. Johann Friedrich Peter, String Quintet no. 4, mvt. 1, mm. 145-52 (viola I and viola II parts)

solo thematic material, double-stop passages, and rhythmically complex parts.

Another important contribution to the viola appeared in 1789: a viola concerto by Peter Albrecht von Hagen (1755-1803). Peter von Hagenand his family-made diverse contributions to concert life, teaching, and music publishing in early America. Active in Charleston as early as 1774, the family had relocated to New York by 1789 , relocating again to Boston seven years later. Von Hagen played and taught multiple instruments including the viola, and he performed his Tenor (Viola) Concerto on a 10 November 1789 recital. ${ }^{31}$ On that same recital, von Hagen's son, Peter Albertus von Hagen (1779/81-1837) (The son's name is also seen as P. A. von Hagen, Jr. or Peter Albrecht von Hagen, Jr., but is now believed to be Peter Albertus von Hagen. He is referred to as Albertus here to differentiate from his father.), also played a "Solo on the Tenor," a rare occurrence-if not the first-when two viola compositions were performed on the same public concert.

The von Hagen family concertized extensively, and the Tenor Concerto was a frequently performed work, primarily by Albertus, who performed on multiple instruments but made a specialty of the viola. The last known appearance of the work at a public concert was on 2 July $1806 .{ }^{32}$ The influence of the work was limited; there is no evidence that

\footnotetext{
31. "Mr. Van Hagen, Lately from Holland, Respectfully Informs the Public, That He Intends Having a Concert, at the City Assembly-Room, on the 10th Inst.," New-York Daily Gazette, 7 November 1789.

32. H. Earle Johnson, "The Musical Von Hagens," New England Quarterly 16, no. 1 (March 1943): 116. The family changed the spelling from van Hagen to von Hagen after their move to Boston (see p. 112).
} 
the concerto was taken up by other performers, and the work is presumed lost. But the repeat performances of the concerto suggest a respectable reception by audiences.

In addition to the concerto and the "Solo on the Tenor," the von Hagens also advertised a "Duo for the tenor and Violin," performed by father and son, ${ }^{33}$ and a duetto for pianoforte and tenor, performed by Albertus and John Christopher Moller. ${ }^{34}$ While the concerto is the only work that can positively be ascribed to the hand of Peter von Hagen, these other viola works may also have been composed by him. One performance by Albertus of an identifiable work occurred on 26 September 1805, when he played a viola concerto by Franz Hoffmeister in Boston. ${ }^{35}$

Given the numerous solo appearances, Peter Albertus von Hagen can be regarded as the first viola soloist in America. Though his efforts are not as well-known as his European contemporaries, his contributions and his father's to the viola as a solo instrument were substantial. Sadly, Albertus gradually descended into alcoholism, and he is last heard of in 1833, when he played viola in the Tremont Theatre in Boston. ${ }^{36}$

1789 was only the beginning for the viola as a solo instrument in America; over the next few decades, the viola would prosper. This followed the trend in Europe, where the viola found a greater appreciation with the ascendance of the galant and classic styles. Alessandro Rolla and Carl and Anton Stamitz were the major proponents for the viola as a solo instrument (Rolla composed more than twenty concertante works for the viola), but other performers, including Benjamin Blake in England and Johann Georg Hermann Voigt in Germany, were also active champions.

Popular European viola works performed in America include violin and viola duets by Rolla and Carl Stamitz, as well as sinfonie concertanti by Ignace Pleyel and Jean-Baptiste Davaux. ${ }^{37}$ Widely performed were the sonatas for viola and bass by František Kocžwara. Largely forgotten today, these sonatas were published in editions in England, France, and Germany during the 1780s. The immense success of Kocžwara's Battle of Prague and the ready availability of the music would have made these an

\footnotetext{
33. "Subscription Concert. The First Violin by Mr. Van Hagen," Daily Advertiser (New York), 4 March 1791.

34. "Old City Concert," Daily Advertiser (New York), 20 January 1796.

35. "Concert Hall," Columbian Centinel (Boston), 25 September 1805.

36. Songs, Duets, Concerted Pieces, and Choruses, in the White Lady, or Spirit of Avenel, a Romantic Opera, in Three Acts, with the Original Music by Boieldieu, with Additions from Weber, Rossini, and Guglielmi (Boston: Dutton and Wentworth, 1833), [2].

37. Davaux's (for two violins and viola) and Pleyel's (for violin and viola) were performed in Charleston, among other places. See Nicholas Michael Butler, Votaries of Apollo: The St. Cecilia Society and the Patronage of Concert Music in Charleston, South Carolina, 1766-1820 (Columbia: University of South Carolina Press, 2007), 330.
} 
attractive choice for concert programs. The Moravian Music Foundation collection contains the German edition, and at least one performance of the first sonata is known in one of their settlements. ${ }^{38}$ The sonatas were also performed by other musicians, including several performances by the noted violinist George Gillingham in Baltimore and Philadelphia.

While European viola works were programed, only a few American composers were writing works for the viola. James Hewitt (1770-1827) wrote a duet for flute and tenor, and he performed an unidentified concerto for viola, possibly his own. ${ }^{39}$ More unfortunate is the lack of published works for the viola. Despite compositions by Peter von Hagen and James Hewitt, two of America's earliest music publishers, there are no known published works for solo viola prior to 1875 . The time and cost involved, as well as anticipated low sales, would not have warranted the publishing of viola works when they could be imported much more cheaply. Additionally, works for the violin could easily be adapted by violists, either with violists transposing the violin part down a fifth, or by playing the notated pitches, transposing down an octave any sections that would go beyond first position.

\section{MIDCENTURY PROGRESS: 1840-1875}

The middle of the nineteenth century saw a rapid development of musical life in America, and the rise of orchestras and chamber ensembles increased opportunities for violists. Several substantial viola compositions received their American premieres, and the earliest surviving American viola solo compositions also date from this period.

The first important compositions for viola from this period are George Frederick Bristow's duos for violin and viola. A violinist in the New York Philharmonic Society beginning in the group's second season (184344), Bristow (1825-1898) would play a pivotal role in the efforts of American composers to earn a place on concert programs. Remembered more for his later large-scale orchestral and choral works, Bristow's early works are primarily songs and smaller chamber music pieces. The two extant duos (Duo no. 2 and Duo no. 3) date from 1845, and demonstrate technically demanding and thematically interesting parts for the viola. The second movement of the Duo no. 2, for example, gives the melody almost entirely to the viola (fig. 4).

Despite Bristow's importance as an American composer, the historical value of these duos, and the availability of the manuscripts, neither a published edition nor a recording of these duos has been produced. The

38. Barbara Jo Strauss, "A Register of Music Performed in Concert, Nazareth, Pennsylvania, from 1796 to 1845: An Annotated Edition of an American Moravian Document" (M.Mus. thesis, University of Arizona, 1976), 41.

39. “Concert \& Ball. Dr. Jackson's Concert,” New-York Evening Post, 17 January 1805. 

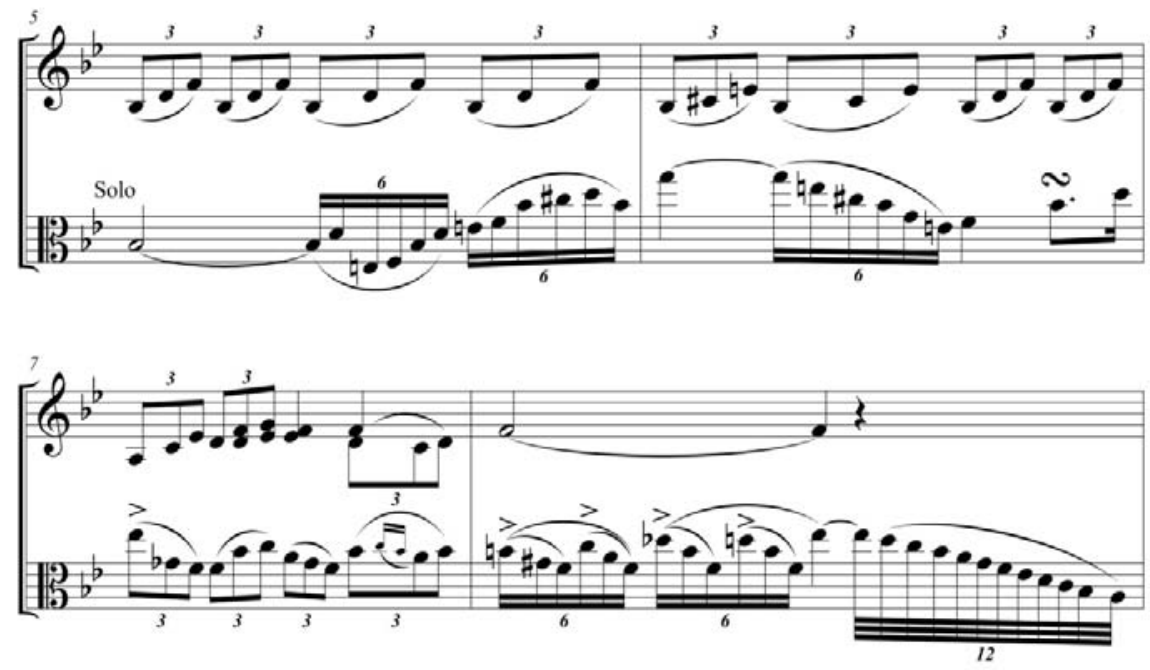

Fig. 4. George Frederick Bristow, Duo no. 2 for violin and viola, mvt. 2, mm. 5-8

disregard of the duos is evident when reviewing the manuscripts: the works contain extensive, awkward double-stopping for both instruments, making them impractical to play. The work would seem a likely candidate for a new edition by the AVS, and while an "urtext" edition would be valuable from a historical perspective, a modern performing edition that mitigates the problematic part-writing could help these duos reach a broader audience.

One recently rediscovered work by another influential nineteenthcentury musician is Theodore Thomas's Divertissement for viola and piano, published in 2010 by the AVS. Noted more for his skills as a conductor and violinist, Thomas (1835-1905) also composed and arranged music. As an essentially self-taught musician, Thomas's lack of formal training and a punishing conducting schedule did not allow much time for composing, and the few compositions he managed to produce were not well-received. ${ }^{40}$ Composed in 1860 , the Divertissement is his earliest known work, and demonstrates a capable command of melodic and harmonic writing. Highly virtuosic, the Divertissement begins with a rhapsodic introduction before launching into a spirited bolero. The enchanting composition is perhaps most noteworthy for its technical demands, which would have required a very skilled violist to perform (fig. 5). The violist in this case was George Matzka (1825-1833), Thomas's friend and violist

\footnotetext{
40. Ezra Schabas, Theodore Thomas: America's Conductor and Builder of Orchestras, 1835-1905, Music in American Life (Urbana: University of Illinois Press, 1989), 25-26.
} 

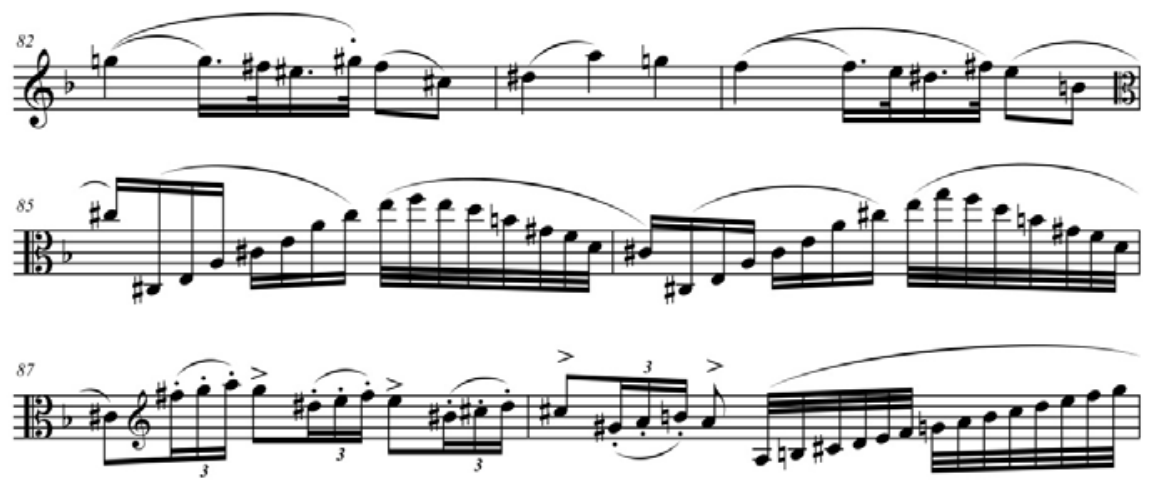

Fig. 5. Theodore Thomas, Divertissement for viola and piano, mm. 82-88 (viola part)

in the Mason-Thomas String Quartet, for whom the work was written and who premiered it.

In addition to composing for the viola, Thomas was known to have played viola in chamber concerts, but his lasting contribution to the viola was as a conductor and programer. In 1863, he conducted the American premiere of Hector Berlioz's Harold in Italy for viola and orchestra, with the violinist Edward Mollenhauer as soloist. Thomas would program this work frequently over the course of his career, taking the work on one of his tours during the 1874-75 season. In 1865, he premiered Mozart's Sinfonia Concertante in E-Flat for violin, viola, and orchestra, K. 364; Thomas took the violin solo, and Matzka took the viola part. Thomas programed other significant viola works over his lengthy career: Bach's third and sixth Brandenburg concertos, Strauss's Don Quixote, and Hans Sitt's Viola Concerto. Thomas's frequent programing of viola music is particularly impressive, given that European conductors mostly ignored the viola as a solo instrument during the middle of the nineteenth century.

So, while there were earlier contributions to the advancement of the viola as a solo instrument in America, it is Thomas, as conductor and programer, who made the first widespread and lasting contributions to the viola's progress here. This is most evident in his championing of Harold in Italy, in particular Thomas's Boston premiere of the work in 1874. Thomas was greatly admired in Boston, and his performance sparked great interest for the composition in that city. ${ }^{41}$ The Boston Symphony, founded in 1881, would program the work during six seasons

41. The initial critical response, however, was not enthusiastic: "We were not alone in our impression of the dreariness of the Programme Symphony of Berlioz, performed in the first Thomas Symphony Concert." Unsigned review of Harold in Italy, in Dwight's Journal of Music 34, no. 16 (14 November 1874): 336. 
in the nineteenth century alone, ${ }^{42}$ and the ensemble under Sergey Koussevitzky would make the first recording of the work in 1944 with William Primrose as soloist (Primrose also would record the work with the orchestra under Charles Münch in 1958).

Thomas was also largely responsible for the emergence of the two most prominent mid-nineteenth-century viola soloists in the United States. The first, George Matzka, was born in Germany in 1825 and came to America in 1852, joining the New York Philharmonic as a violist in the 1853-54 season and serving as principal violist for many years. Despite his position there, he appeared as soloist only once with the orchestra, in a performance of Spohr's Quartet Concerto, op. 131, in 1858. It was his relationship with Theodore Thomas, performing Harold in Italy and Mozart's Sinfonia Concertante, that garnered him more success. Matzka also inspired new works: in addition to Thomas's Divertissement, Fidelis Zitterbart's (1845-1915) first viola sonata was dedicated to Matzka. Though Matzka did compose, he wrote no known works for viola.

Charles Baetens (1826-1908) was the other prominent violist who shared a successful professional relationship with Thomas. Previously the principal violist with the Hallé Orchestra, Baetens came to America in 1871 to serve as principal of the Thomas Orchestra. ${ }^{43}$ He appeared as soloist in Harold in Italy during an orchestral tour 1874-75, and when Thomas was appointed to direct the new College of Music of Cincinnati, Baetens was hired to teach violin and viola and serve as principal in the orchestra associated with the school. In Cincinnati, Baetens appeared frequently as a viola soloist, playing standard romantic works by Joachim and Schumann as well as his own original viola compositions. Unfortunately, none of these compositions are known to have survived.

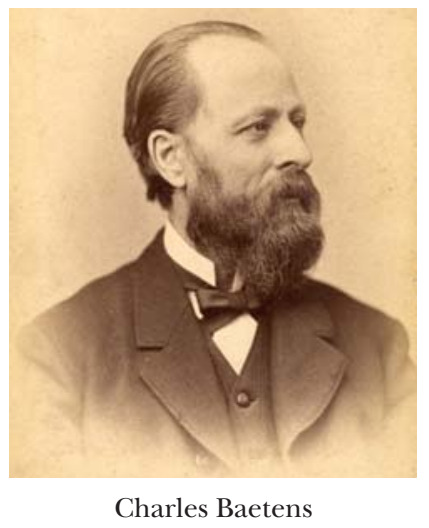

42. H. Earle Johnson, Symphony Hall, Boston (Boston: Little, Brown, 1950), 320.

43. For more biographical information on Baetens, see David M. Bynog, "Charles Baetens: Portrait of a Nineteenth-Century Violist,” American String Teacher 59, no. 4 (November 2009): 46-49. 


\section{GOING MAINSTREAM: 1875-1900}

By the end of the nineteenth century, European artists-including Hermann Ritter, Oskar Nedbal, and Théophile Laforge-began specializing in the viola and generating enthusiasm for the instrument. In the United States, the viola saw continued promotion by soloists, but the greatest advancement for the viola at the end of the nineteenth century was born of new efforts by American composers, publishers, and amateurs.

Music making at home became a great pastime of Americans during the late nineteenth century. The growing interest in the viola by amateurs and students spurred publishers, who clearly saw this market and aimed their early efforts at it. Viola methods appeared through the end of the century; many were part of a series of tutors for various instruments, and were designed for individuals who wished to learn the instrument by themselves. Winner's Eureka Method for the Viola, Otto Langey Tutor, and White's Excelsior Method for the Viola were a few popular titles. The earliest known published work in America is an edition of Antonio Bruni's Méthode pour l'alto viola, published by Oliver Ditson in 1875. Bruni's method had widespread popularity from its first European edition in 1805, and several American editions were published after Ditson's. ${ }^{44}$ Bruni's original method was not intended for beginners, but rather for advanced violinists ${ }^{45}$ and so it is atypical of the majority of viola methods that were produced in nineteenth-century America.

Original music was also aimed at amateurs, with the Cincinnati-based music publisher John Church publishing a series of artistic solos for viola by popular composers. By the 1890 s, popular interest in the viola was so substantial that the mail-order merchant Montgomery Ward was selling three affordable models of "Violas or Tenor Violins" (each with an instruction book) in its catalog. ${ }^{46}$ The rival Sears, Roebuck \& Co. included three violas when it added musical instruments to its catalog in 1894, and offerings were soon expanded to include viola supplies. ${ }^{47}$

One of the musicians included in John Church's series by popular composers was Fidelis Zitterbart. Born into a musical family in Pittsburgh in 1845, Zitterbart trained there as a violinist before heading to Dresden at age sixteen for further studies. ${ }^{48}$ Upon his return to the United States, he performed as a violinist with organizations in New York, including the New York Philharmonic, where he performed as a violist during the

44. Maurice W. Riley, The History of the Viola, 2 vols. (Ann Arbor, MI: Braun-Brumfield, 1980), 1:181.

45. Ibid.

46. "Violas or Tenor Violins," Montgomery Ward Eं Co. Catalogue and Buyers' Guide 57 (1895): 245.

47. "Viola Furnishings," Sears, Roebuck and Co. Consumers Guide (Fall 1896-97): 665.

48. For additional information on Zitterbart, see Robert F. Schmalz, "The Zitterbart Collection-A Legacy Unevaluated," College Music Symposium 19, no. 2 (Fall 1979): 77-88. 
1869-70 season. Zitterbart returned to Pittsburgh in 1873 to teach at the American Conservatory of Music, and he remained there as an active part of Pittsburgh's musical life until his death in 1915.

In addition to his work as a performer and teacher, Zitterbart was a prolific composer. He left nearly fifteen-hundred compositions, the manuscripts of which now reside in the Special Collections Department, Hillman Library, University of Pittsburgh. Zitterbart published very few of his compositions, and researchers are only now beginning to investigate the materials in the Zitterbart Collection. Plans by the University of Pittsburgh to digitize the collection will open up a better understanding of his contributions to nineteenth-century musical life in America.

The collection contains a remarkable number of compositions for viola: nearly fifty works for viola and piano as well as small ensemble pieces that include the viola. Most of these works are short salon pieces with whimsical names: Ben-Hur, The Lighthouse, and Evening Reverie are just a few. While many of these works were clearly aimed at amateur violists, the collection also includes larger works intended for professionals. Among these are thirteen sonatas for viola and piano, the earliest dating from 1875-the first known American viola sonata-and is dedicated to George Matzka, whom Zitterbart knew from his time with the New York Philharmonic. The three works published by John Church-Spanish Serenade, Lied ohne Worte, and Barcarolle-have been scanned and added to the American Viola Project, and the AVS plans to edit and publish additional works by Zitterbart.

The small amount of published music has been a significant deterrent to the dissemination and survival of early American viola music, so violists are fortunate that chamber works by Charles Martin Loeffler (1861-1935) were published by Schirmer in the early 1900s. While Loeffler's compositions were frequently performed and highly regarded, only a small amount of his output was published during his lifetime. The publication of these works-among Loeffler's earliest—demonstrates the high regard that Loeffler and the publisher Schirmer held for them, and the growing influence of the viola on publishers.

Primarily a violinist, Loeffler also played viola and viola d'amore. From 1893 to 1894 he composed nine songs for voice, viola, and piano, of which four-Harmonie du soir, Dansons la gigue!, La cloche fêlée, and Sérénade—received a public performance in 1897, with Loeffler playing the viola part. ${ }^{49}$ Three of these songs (Dansons la gigue!, La cloche fêlée, and

49. Ellen Knight, Charles Martin Loeffler: A Life Apart in American Music, Music in American Life (Urbana: University of Illinois Press, 1993), 93-94, 110. 
Sérénade) were published with the song Le son du cor s'afflige vers les bois as Quatre poëmes, op. 5, in 1904 by Schirmer. ${ }^{50}$

Loeffler's other contribution to viola chamber music dates from 1901: the Deux rapsodies, for oboe, viola, and piano. ${ }^{51}$ Loeffler premiered these later that year and frequently performed them. All of these viola works display Loeffler's symbolist style to great effect. Particularly striking is Loeffler's use of color, not only through string techniques including pizzicato, sul ponticello, harmonics, and con sordino, but in his general understanding of the tonal qualities of the viola. The songs display his best viola writing, but the Deux rapsodies are amply effective. A favorite of violists, the Deux rapsodies are Loeffler's most recorded works.

\section{A NEW BREED OF VIOLISTS: 1900-1920}

A flowering of the viola as a solo instrument occurred during the first two decades of the twentieth century. The prime motivator behind this was Lionel Tertis (1876-1975) - who would make many trips to the United States-but other violists were also championing the cause of the instrument. The growth of professional orchestras in the United States led to a greater need for violists, and the country's economic opportunities attracted many prominent artists. In the years leading up to 1920, several violists appeared who would make substantial contributions to the growth of the instrument.

America's first viola soloist of great renown was Émile Férir (18731949). Born near Brussels, Férir studied violin with Eugène Ysaÿe and viola with Léon Firket. ${ }^{52}$ Férir served as principal viola of the Queen's Hall Orchestra from 1896 to 1902, and left England to serve as principal of the Boston Symphony beginning in 1903. Immediately prior to sailing for America, Férir premiered a new concerto by Cecil Forsyth at a Promenade Concert. The viola concerto, as a genre, had suffered during the nineteenth century, and this new concerto by Forsyth was an instant success, bringing repeat performances and ushering in a new age of works for viola and orchestra.

In Boston, Férir appeared as soloist numerous times with the Boston Symphony, giving multiple performances of Harold in Italy, Don Quixote, and Mozart's Sinfonia Concertante. Gustav Strube, a violinist in the Boston Symphony, composed two pieces for viola and orchestra for Férir:

50. The remaining five songs were published in: Charles Martin Loeffler, Selected Songs with Chamber Accompaniment, ed. Ellen Knight, Recent Researches in American Music, 16 (Madison, WI: A-R Editions, 1988).

51. These pieces are a revision of two vocal rhapsodies composed in 1898 and originally scored for voice, clarinet, viola, and piano. See Loeffler, Selected Songs with Chamber Accompaniment.

52. Thomas Heimberg, "Remembering Émile Férir," Journal of the American Viola Society 17, no. 3 (2001): 21 


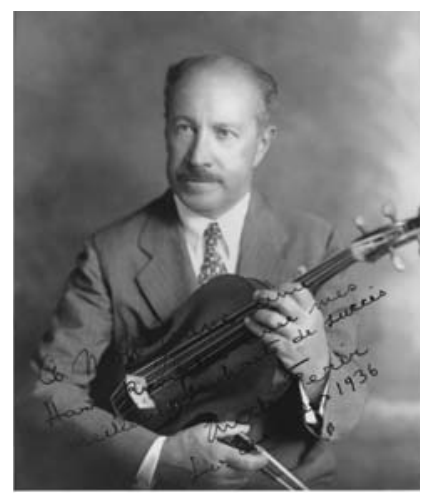

Émile Férir

Longing and Fantastic Dance, which received repeat performances. Férir was active in chamber music, giving solo recitals and performing in Boston with quartets-most notably the Hess-Schroeder and Boston Symphony Quartets. He premiered Arthur Foote's Sarabande and Rigaudon, for oboe (or flute), viola (or violin), and piano (composed in 1921), and was likely the inspiration behind Foote arranging for viola his Melody, for violin and piano. ${ }^{53}$

Férir left the Boston Symphony in 1918; he held a variety of positions (including principal of the Philadelphia Orchestra) before assuming the position of principal violist with the Los Angeles Philharmonic in 1921. Férir also appeared as soloist in Los Angeles, and during the early 1920s he performed several of his own compositions for viola and orchestra with the Los Angeles Philharmonic and the Cincinnati Orchestra.

Unfortunately, Férir's contributions to the development of the viola have been underappreciated owing to a lack of surviving material. He made no recordings (a deficiency for all American violists until the appearance of William Primrose in the 1930s), he edited no music, and only a few of his compositions were published. His residency in Boston initially placed him in the center of classical music activities, but this changed with his departure to Los Angeles, and a number of new violists stepped in to fill the void on the East Coast.

Other violists during this period proved influential in different ways. Louis Svečenski (1862-1926), born in Croatia and trained on violin at the Vienna Conservatory, came to America to perform with the Boston Symphony. Svečenski would go on to great frame as the violist with the

53. The manuscript for the Melody contains the note: "sent to E. Férir [and] Adeline Packard." The reworking of Foote's Cello Sonata for viola may also have been intended for Férir, or, given the 1919 date on the manuscript, the work may have been intended for the Berkshire Festival Competition. 
Kneisel Quartet, a position that he held throughout the ensemble's thirty-two-year history. In 1916, he produced the earliest known complete edition of Bach's Six Cello Suites transcribed for viola, published by Schirmer. ${ }^{54}$ Svečenski taught Lillian Fuchs (1903-1995), who would champion these suites and become "one of the first violists to include Bach cello suites on concert programs and, more importantly, was the first violist to record them." 55 So, while European violists were slow to recognize the value of these works, American violists-beginning with Svečenski-were establishing these pieces as a cornerstone of the standard repertoire. ${ }^{56}$

Louis Bailly (1882-1974), who had trained in France, initially specialized in chamber music, and in 1917 he came to the United States to replace Ugo Ara as violist in the Flonzaley Quartet. During Bailly's tenure, the quartet performed compositions that reflected the growing interest in music incorporating distinctly American themes, including Charles Griffes's Two Sketches Based on Indian Themes, Daniel Gregory Mason's String Quartet in G Minor (Based on Negro Themes), and arrangements of spirituals, plantation songs, and popular American music. ${ }^{57}$ As a soloist, Bailly premiered Ernest Bloch's Suite (in versions for viola and piano, and viola and orchestra) and Rebecca Clarke's Viola Sonata, and Gustav Strube and Henry Joslyn composed works for him. His most lasting contribution, however, was in his position as viola professor at the newly founded Curtis Institute of Music, where he taught from 1925 to 1941. The viola had received little specialized study in America prior to this point, and Bailly was an early advocate for it, noting that a focused class "would give new direction to the viola in the country." 58 Bailly did succeed in giving new direction as an educator; his class served as a model for other institutions, and he instructed several violists who went on to prominent careers, including Max Aronoff, Joseph de Pasquale, Leonard Mogill, and Virginia Majewski.

\footnotetext{
54. Hermann Ritter produced an edition of the first four suites in the nineteenth century: J. S. Bach, Sonaten für die Altgeige (viola alta) allein: Suite 1-4, ed. Hermann Ritter (Leipzig: Carl Merseburger, 1885).

55. Amédée Daryl Williams, Lillian Fuchs: First Lady of the Viola, 2d rev. ed. (New York: iUniverse, 2004), 86.

56. Prior to the twentieth century, most works transcribed for viola were intended as Hausmusik, and were seldom programed on public recitals. The attitude toward transcriptions changed dramatically as twentieth-century viola soloists sought ways to expand the repertoire with a particular desire to perform works by composers in the musical canon.

57. The group's arrangements of American folk and plantation songs by Alfred Pochon included Old Black Joe; Angel Gabriel; Go Down, Moses; Swing Low, Sweet Chariot; Deep River; and Turkey in the Straw. See Flonzaley Quartet Favorite Encore Albums, compiled by Alfred Pochon, 4 vols. (New York: Carl Fischer, 1920-28). The quartet also played works by other American composers during Bailly's tenure including Charles Martin Loeffler, Ernest Bloch, and George Templeton Strong. See Kimberly Schafer, "From Conservatism to Modernism through the Music of the Flonzaley String Quartet" (M.Mus. thesis, University of Texas at Austin, 2004).

58. "Louis Bailly on Viola Playing," Christian Science Monitor, 29 June 1918.
} 


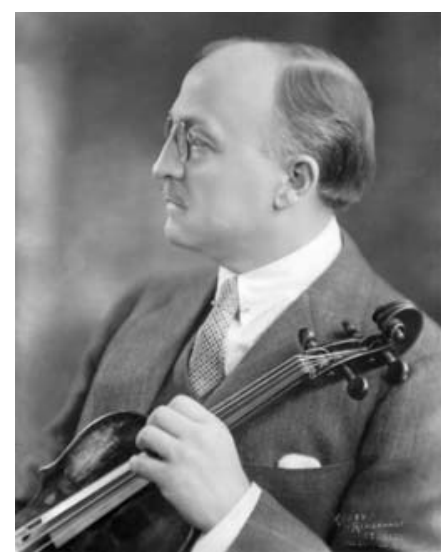

Louis Bailly (photographer Kubey-Rembrandt Studios, courtesy of the Curtis Institute of Music)

The early part of the twentieth century also afforded greater opportunities for women: "The study of the Viola at the present time is not confined, as formerly, to men performers, but numbers in almost every musical community many women players who are skilled executants. As a natural result, instrumental music in which it finds a proper place has been greatly benefitted." 59 While women violists had been performing in America prior to this period, they were now coming to greater prominence as solo violists. One of the earliest, Blanche Blood, trained in Chicago and played violin, viola, and viola d'amore. ${ }^{60}$ Also a teacher and composer, she published a Barcarolle, for viola and piano in 1906, presumably the earliest viola composition by an American woman. This work, which has also been published in a new edition by the AVS, was "especially adapted to the deep toned effects of the viola" (title page of the AVS edition).

Though the composer and violist Rebecca Clarke (1886-1979) was born and educated in England, her father was American, thus granting her American citizenship. ${ }^{61}$ She studied composition at the Royal College of Music with Charles Stanford, and switched from violin to viola at his suggestion. Clarke came to the United States for several extended stays

59. White's Excelsior Method for the Viola: Without a Teacher the Best and Latest Instructor (Boston: WhiteSmith Music, 1900), 11.

60. Earl R. Drake Company ([Chicago?]), http://sdrc.lib.uiowa.edu/traveling-culture/chau1/pdf /earlr/1/brochure.pdf (accessed 22 February 2012).

61. Rebecca Clarke, "Rebecca Clarke's 1977 Program Note on the Viola Sonata," in A Rebecca Clarke Reader, ed. Liane Curtis (Bloomington: Indiana University Press, 2004), 226. 
and permanently settled here during World War II. A period of touring in America was highlighted by two New York recitals at Aeolian Hall: The first was a joint recital with cellist May Mukle on 13 February 1918. There she performed her Lullaby and Grotesque for viola and cello as well as her Morpheus for viola and piano (fig. 6). ${ }^{62}$ At the second, a joint recital with pianist Winifred Christie on 26 January 1920, she performed her Viola Sonata and premiered Caprice Basque, a work by fellow violist Émile Férir. Clarke, like all of the prominent violists of this period (Férir, Svečenski, Bailly, and others), made virtually no recordings, and her compositions have been revived in recent times largely thanks to the determined efforts of the Rebecca Clarke Society.

Just as the cause of the viola as a solo instrument in the nineteenth century received much promotion from the conductor Theodore Thomas, the viola also received help from an outside source at the beginning of the twentieth century. In this instance, the catalyst was Elizabeth Sprague Coolidge (1864-1953), patron of the arts and great admirer of the viola. In 1917, Coolidge fulfilled her dream of an arts colony in Pittsfield, Massachusetts. ${ }^{63}$ She announced the Berkshire Festival Competition, which would award a prize of $\$ 1,000$ for the best string quartet at the first Berkshire Festival in September 1918. Following that successful event, Coolidge selected the instrumentation of viola and piano for the next year's competition, influenced by her son Sprague's study of the viola at the time. ${ }^{64}$ The 1919 competition attracted seventy-two entries from around the world; the entries were known to the six judges only by a pseudonym: "What you did was sent an envelope to accompany the work. In the envelope was your name and address and on top of the envelope was a pseudonym. So that all they knew was the pseudonym. But they knew which was Bloch, because Bloch was unmistakable."65

The balloting resulted in a split vote between Ernest Bloch's Suite and Rebecca Clarke's Viola Sonata, and Coolidge was brought in to break the tie. Knowing the identity of the composers (who were both friends of hers), she selected Bloch's Suite as the winner, basing "her decision strictly upon 'ethical and not personal lines." "66 Though the rules of the contest required the name of only the winning composer to be revealed,

\footnotetext{
62. "Programmes for the Week," New-York Tribune, 10 February 1918. Morpheus was programed under Clarke's male pseudonym, Anthony Trent.

63. Cyrilla Barr, Elizabeth Sprague Coolidge: American Patron of Music (New York: Schirmer Books, 1998), 133-35.

64. Kevin LaVine (senior music specialist, Library of Congress), e-mail message to author, 31 January 2011.

65. Rebecca Clarke and Robert Sherman, "Robert Sherman Interviews Rebecca Clarke about Herself," in A Rebecca Clarke Reader, 174.

66. Barr, 142
} 


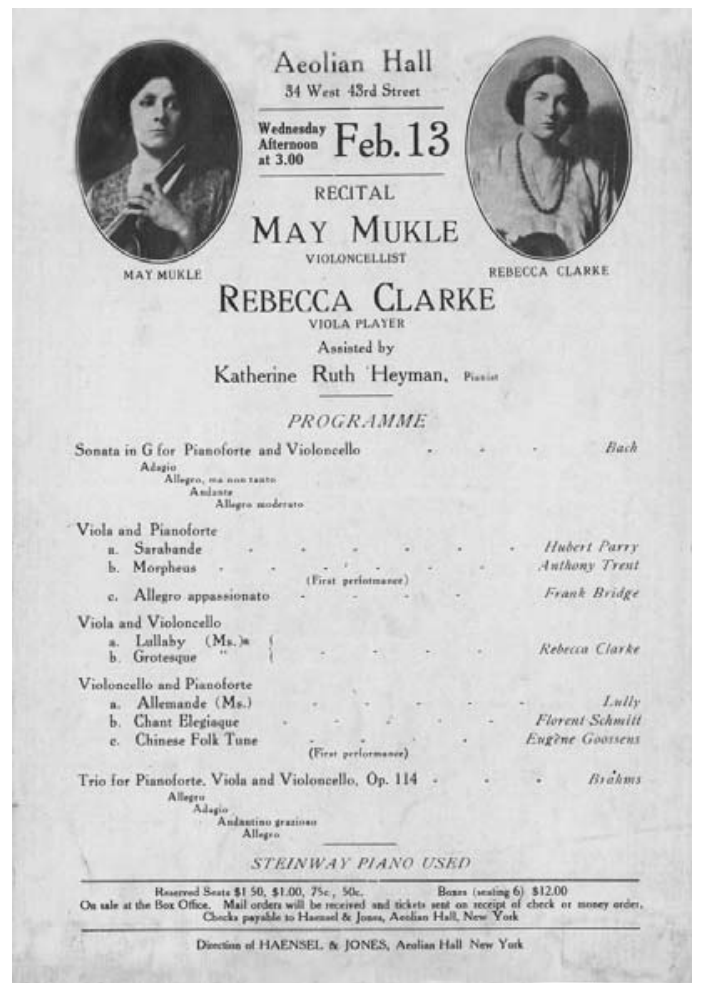

Fig. 6. Program from Rebecca Clarke's 13 February 1918 recital with cellist May Mukle (courtesy of Heidi Schultz, Liane Curtis, and the Rebecca Clarke Society)

the judges demanded to know the identity of the other composer, and during the festival, both works were performed by Louis Bailly and Harold Bauer. Bloch's work was an immediate success and quickly taken up by violists. Clarke's Viola Sonata gained some attention (Louis Bailly routinely taught the work while he was at Curtis), but it did undergo a period of neglect until the late 1970s; since then it has also become a staple of the viola solo repertoire.

\section{CONGLUSION}

For most violists, 1919 marks the beginning of the instrument's history in America. And with its surrounding publicity resulting in the production of two masterpieces, the 1919 Berkshire Festival Competition is the event that established America as an emerging center for the viola. With the rapid development of the viola over the next few decades-through 
America's educational institutions, a new generation of soloists (led by William Primrose), and a wave of extraordinary compositions (most notably Béla Bartók's Viola Concerto) - 1919 was, indeed, just the beginning for the viola in America.

But 1919 was also the culmination of two centuries of viola progress. Though activities were scattered and disparate, the viola made progress through soloists, composers, chamber and orchestra music, luthiers, patrons, and audiences. The viola was most successful when it appealed to Americans' interest in the exotic: as a romantic poet in Harold in Italy or a buffoonish sidekick in Don Quixote or in the symbolist chamber music of Loeffler and the orientalist works of Bloch and Clarke. But, even in the more traditional and pragmatic efforts, the viola was an integral part of the musical culture of America.

\section{ABSTRACT}

Research on the viola in America has largely been confined to activities in the twentieth century. Recent efforts by the American Viola Society, notably the American Viola Project-which aims to preserve American viola compositions-have focused on the early history of the viola. This article provides a broad overview of the viola from the colonial period through 1920 .

From the eighteenth century, contributions by members of Moravian settlements are highlighted. A viola concerto by Peter Albrecht von Hagen and solo viola performances by his son, Peter "Albertus" von Hagen, are also detailed.

In the nineteenth century, Theodore Thomas served as a great promoter of the viola, both through his programing of music and in his association with the viola soloists George Matzka and Charles Baetens. The viola also benefitted from increased interest by amateurs, composers, and publishers. The most well-known efforts are Charles Martin Loeffler's chamber works, which have remained a staple of the viola repertoire.

A number of prominent viola soloists appeared in the twentieth century including Emile Férir, Louis Svečenski, Louis Bailly, and Rebecca Clarke. 1919 was a turning point for the viola with the Berkshire Festival Competition for Viola and Piano, resulting in a tie between Ernest Bloch's Suite and Rebecca Clarke's Viola Sonata. 